\title{
STUDY THE IMPACT OF DISTURBANCE FULFILLMENT SEXUALITY NEEDS AFTER HEART ATTACK ON ACUTE MYOCARDIAL INFARCTION IN MEN PATIENTS ON CARDIAC POLY CLINIC Dr. ISKAK HOSPITAL TULUNGAGUNG
}

\author{
Eko Arik Susmiatin, Rika Yolanda Sarite \\ * Perawat di Rumah Sakit Pusat Kanker Darmais Jakarta
}

\begin{abstract}
Basic human needs is the most basic physiological needs, including sexual needs in it. Sexual fulfillment in the husband-wife not everything can be done well because of several factors, one of them due to heart disease (acute myocardial infarction). AMI patients are usually the same as the other pair, really wants her sexual needs fulfilled, but they are afraid to do it because they fear an attack recurrence. Impacts that could result from unfulfilled sexual needs including couples will quickly get angry or suspicious, unhappy, cynical, psychological relation between husband and wife is getting worse, decreasing the frequency of coitus, having psychosomatic illness. The research objective was to determine the impact of sexual fulfillment disorders after cardiac arrest in patients with acute myocardial infarction (AMI) in men Poly Clinic Heart Dr.Iskak Hospital Tulungagung. The study design used is descriptive design. Population of outpatients each month reaches $5-8$, the sample used 8 people, taken with accidental sampling technique. Results of research obtained from all respondents stating no interference effects occur sexuality needs. This is due to the coping meccanism of the respondent and couple, and mutual understanding, and the support the family, so there is no impact of interference sexuality needs.Expected partner (wife) will understand situation the disturbed husband after Acute Myocardial Infarction attack occurred, and should be more active respondents also asked the doctor when the control, so the impact was not to happen. And for nurses, should provide health education about sexuality needs of post-heart attack.
\end{abstract}

Keywords: effects of disturbance, sexual needs, acute myocardial infarction,men.

\section{PENDAHULUAN}

Kebutuhan dasar manusia yang paling mendasar adalah kebutuhan fisiologis, didalamnya termasuk kebutuhan seksual. Kebutuhan seksual adalah kebutuhan dasar manusia berupa ekspresi perasaan dua orang individu secara pribadi yang saling menghargai, memperhatikan, dan menyayangi sehingga terjadi sebuah hubungan timbal balik antara kedua individu tersebut (Hidayat, 2006). Kesehatan seksual didefinisikan sebagai pengintegrasian aspek somatik, emosional, intelektual, dan sosial dari kehidupan seksual, dengan cara yang positif memperkaya dan meningkatkan kepribadian, komunikasi, dan cinta (Perry \& Potter,2005).

Pemenuhan kebutuhan seksual bisa dilakukan dengan beberapa cara diantaranya sentuhan, ciuman, dan senggama seksual (secsual intercouse), dan melalui perilaku yang lebih halus, seperti isyarat gerak tubuh, etiket, berpakaian, dan perbendaharaan kata (Denney \& Quadagno, 1992; Zawid,1994). Pemenuhan kebutuhan seksual pada suami-istri tidak semuanya bisa dilakukan dengan baik oleh karena beberapa faktor, salah satunya karena penyakit jantung (Infark Miokard Akut).

Pasien-pasien pasca serangan IMA memilki masalah keperawatan yang bisa muncul, diantaranya gangguan pemenuhan kebutuhan seksualitas. Pasienpasien IMA biasanya sama seperti pasangan yang lainnya, sangat menginginkan pemenuhan kebutuhan seksualnya terpenuhi, akan tetapi mereka takut untuk melakukannya dikarenakan 
mereka takut mengalami kekambuhan serangan. Riset di Amerika Serikat (AHA, 2007) menunjukkan, banyak pria dan wanita yang takut (karena takut terjadi kekambuhan serangan dan takut meninggal saat sedang berhubungan dan kurang pengetahuan tentang cara melakukan hubungan seksualitas yang benar pasca serangan IMA) melakukan hubungan seks pasca serangan jantung. Sehingga tidak mengherankan bila frekuensi aktivitas seksual cenderung menurun tajam, terutama selama setahun setelah mengalami serangan jantung atau infark miokard akut (IMA). Sebenarnya melakukan hubungan seksualitas dapat dilakukan setelah melalui beberapa tahap latihan.

Tenaga Kesehatan perlu untuk mengatasi masalah seksual sebagai bagian penting dari fungsi fisik secara keseluruhan, bahkan setelah peristiwa yang mengancam jiwa seperti serangan jantung. Program rehabilitasi yang disebut Cardiac Rehabilitation Program adalah program yang banyak dianjurkan oleh dokter jantung setelah pasien mengalami serangan jantung. Rehabilitasi pada klien pasca infark miokard bertujuan menghasilkan suatu perubahan fisiologis dan psikologis yang bermanfaat dengan meningkatkan kapasitas fungsional agar dapat mengembalikan klien pada kehidupan atau keadaan semula. Pada prinsipnya latihan fisik disusun secara individual berdasarkan status medis, profil faktor resiko, stabilitas muskulokeletal, motivasi terhadap latihan, dan hasil EKG (Udjianti, 2010). Bergantung pada kasus individul, pasien dapat kembali melakukam hubungan seksual 5 sampai 8 minggu setelah infark didasarkan pada indeks kesiapan seksual (kemampuan untuk melakukan berjalan cepat atau menaiki dua anak tangga tanpa merasakan nyeri dada) (Ester,2005). Dapat juga dengan melakukan posisi- posisi pasif, misalnya posisi tidur, di mana pasien berada di bawah, menyamping berhadapan muka atau dari belakang, atau juga posisi duduk di mana pasangan berada di atas pasien adalah beberapa posisi yang dianjurkan. Peran perawat untuk mengatasi solusi ini adalah memberikan promosi tentang edukasi seks dan pemeriksaan nilai dan keyakinan seksual dengan jujur dapat membantu dalam mengurangi bias seksual. Klien mebutuhkan informasi yang akurat, jujur tentang efek penyakit pada seksualitas dan cara yang dapat menunjang kesejahteraan (Perry \& Potter, 2005). Pasangan (istri) juga berperan penting dalam proses menuju kesembuhan. Dukungan emosional, pengertian terhadap sakit yang diderita suami, dan tidak menuntut harus terpenuhinya kebutuhan akan pemenuhan seksual, agar secara psikis suami tidak merasa bersalah dan mempunyai semangat untuk terus berusaha latihan supaya bisa sembuh dari penyakitnya.

Penelitian ini bertujuan Untuk mengetahui dampak gangguan pemenuhan kebutuhan seksualitas pasca serangan jantung pada pasien-pasien Infark Miokard Akut (IMA) laki-laki di Poli klinik Jantung RSUD dr. Iskak Tulungagung.

\section{METODE PENELITIAN}

Desain penelitian yang digunakan dalam penelitian ini adalah desain studi deskriptif yaitu suatu metode penelitian yang bertujuan mendeskripsikan (memaparkan) peristiwa-peristiwa penting yang terjadi pada masa kini. Fenomena disajikan apa adanya tanpa manipulasi dan peneliti tidak mencoba menganalisis bagaimana dan mengapa fenomena tersebut bisa terjadi, oleh karena itu penelitian jenis ini tidak memerlukan adanya suatu hipotesis. Pada penelitian ini variabel penelitiannya adalah dampak masalah pemenuhan kebutuhan seksualitas pasca serangan jantung (IMA) laki - laki.

Pengumpulan data yang dipakai dalam penelitian ini adalah kuesioner dan wawancara. Dalam penelitian ini lembar kuesioner digunakan untuk memperoleh 
keterangan dari pasien IMA laki-laki tentang dampak masalah pemenuhan kebutuhan seksualitas. Analisa data dilakukan dengan menghitung prosentase gangguan pemenuhan kebutuhan seksual pada responden.

Tabel $5.1 \quad$ Distribusi karakteristik responden berdasarkan umur, status pekerjaan, pendidikan, lamanya terjadi serangan, dan frekuensi MRS di Poli Klinik Jantung RSUD dr. Iskak Tulungagung pada 2014.

\begin{tabular}{|c|c|c|c|}
\hline No & Karakteristik & Jumlah & $\begin{array}{c}\text { Prosentase } \\
(\%)\end{array}$ \\
\hline \multicolumn{4}{|c|}{ USIA } \\
\hline \multirow[t]{4}{*}{1} & a. 41-50 tahun & 1 & 12.5 \\
\hline & b. $51-60$ tahun & 2 & 25 \\
\hline & c. $61-70$ tahun & 4 & 50 \\
\hline & d. 71-80 tahun & 1 & 12.5 \\
\hline \multirow[t]{5}{*}{2} & Pekerjaan & & \\
\hline & a. Swasta & 1 & 12.5 \\
\hline & b. Pensiunan & 5 & 62.5 \\
\hline & $\begin{array}{l}\text { c. Tukang } \\
\text { becak }\end{array}$ & 1 & 12.5 \\
\hline & $\begin{array}{l}\text { d. Tidak } \\
\text { bekerja }\end{array}$ & 1 & 12.5 \\
\hline \multirow[t]{5}{*}{3} & Pendidikan & & \\
\hline & a. SMP & 1 & 12.5 \\
\hline & b. SMA & 1 & 12.5 \\
\hline & c. SPG & 1 & 12.5 \\
\hline & $\begin{array}{l}\text { d. Sarjana } \\
\text { Lamanya } \\
\text { terjadi } \\
\text { serangan }\end{array}$ & 5 & 62.5 \\
\hline \multirow[t]{6}{*}{4} & a. 1 tahun & 2 & 25 \\
\hline & b. 2 tahun & 4 & 50 \\
\hline & c. 3 tahun & - & 0 \\
\hline & $\begin{array}{l}\text { d. } \quad 4 \text { tahun } \\
\text { Frekuensi MRS }\end{array}$ & 2 & 25 \\
\hline & a. $1 \mathrm{X}$ & 7 & 87.5 \\
\hline & b. $2 \mathrm{X}$ & 1 & 12.5 \\
\hline
\end{tabular}

Bila dilihat dari table 5.1 diatas dapat disimpulkan bahwa umur responden pada penelitian ini di Poli Klinik Jantung sebanyak setengahnya $(50 \%)$ atau 4 responden berumur antara 61-70 tahun. Status pekerjaan mereka sebagian besar $(62.5 \%)$ atau 5 responden adalah pensiunan pegawai negeri. Pendidikan sebagian besar $(62.5 \%)$ atau 5 responden berpendidikan Sarjana. Jika dilihat dari lamanya terjadi serangan setengah dari serponden $(50 \%)$ atau 4 responden sudah mengalami sakit ini selama 2 tahunan. Dan dilihat dari frekuensi terjadinya serangan hampir semua responden $(87.5 \%)$ atau 7 responden hanya mengalami $1 \mathrm{X}$ MRS.

Tabel 5.2 Distribusi prosentase responden berdasarkan terpenuhi dan tidak terpenuhinya kebutuhan seksualitas pasca serangan jantung di Poli Klinik Jantung RSUD dr.Iskak Tulungagung 2014

$\begin{array}{clcc}\text { No. } & \text { Keterangan } & \text { Jumlah } & \% \\ \text { 1. } & \text { Tidak } & 8 & 100 \\ & \text { terganggu } & & \\ \text { 2. } & \text { Tergangggu } & 0 & 0 \\ \text { Total } & & 8 & 100\end{array}$

Bila dilihat dari tabel 5.2 diatas dapat disimpulkan bahwa seluruh responden $(100 \%)$ dengan jumlah 8 orang responden, tidak mengalami dampak gangguan pemenuhan kebutuhan seksualitas pasca serangan jantung, dalam artian mereka merasa terpenuhi pemenuhan kebutuhan seksualitasnya

\section{PEMBAHASAN}

Berdasarkan hasil penelitian dari jumlah responden sebanyak 8 responden, seluruh responden $(100 \%)$ menyatakan tidak mengalami dampak gangguan dalam pemenuhan kebutuhan seksual.

Kebutuhan seksualitas adalah kebutuhan dasar manusia berupa ekspresi dua orang individu secara pribadi yang saling menghargai, memperhatikan, dan menyayangi sehingga terjadi sebuah hubungan timbal balik antara kedua individu tersebut (Hidayat,2006). Atau kesehatan seksual didefinisikan sebagai pengintegrasian somatik, emosional, intelektual, dan sosial dari kehidupan seksual, dengan cara yang positif memperkaya dan meningkatkan kepribadian, komunikasi, dan cinta (Perry 
\& Potter, 2005). Pria tidak mengalami perubahan hormonal yang dramatis atau kehilangan fertilisasi seperti yang dialami oleh wanita menopouse. Namun demikian mereka mengalami perubahan dalam respon seksual atau klimakterik. Pada usia 90 tahun, seorang pria mungkin mampu untuk sprematogenesis. Namun demikian, perlambatan kemampuan erektil dan ejakulatori yang dialami pada usia 50 atau 60 tahunan dapat menyebabkan kekhawatiran yang signifikan tentang potensi dan maskulinitas. Kebutuhan seksualitas merupakan kebutuhan dasar manusia yang juga harus terpenuhi seperti halnya makan dan minum. Akan tetapi, kita tidak bisa memaksakan pemenuhan kebutuhan seksual tersebut bisa terpenuhi pada pasien-pasien jantung, terutama Infark Miokard Akut ( IMA ). Karena suatu penyakit respon terhadap pemenuhan kebutuhan seksual pun ikut berubah. Alat genetal dan jaringan lunak tubuh lainnya yang berespon terhadap rangsangan seksual membutuhkan pasokan darah yang adekuat, karena suatu penyakit alat genetal dan jaringan lunak tubuh mengalami penurunan respon. Hormon mempengaruhi suasana hati seksual dan fungsi fisiologis dalam ekspresi seksual. Persendian dan otot harus menekuk dan meregang ketika tubuh memberikan ekspresi terhadap perasaan seksual. Suatu perubahan dalam sistem ini, klien mungkin harus mempelajari perilaku seksual yang baru. Perubahan dalam fungsi dan struktur tubuh sebagai akibat dari suatu penyakit mungkin tidak secara langsung mempengaruhi seksualitas tetapi dapat mempengaruhi perasaan-perasaan dan persepsi klien dalam hal keinginan dan rangsangan. Beberapa dampak yang dapat ditimbulkan akibat tidak terpenuhinya kebutuhan seksualitas, diantaranya sebagi berikut pasangan akan cepat marah, tidak bahagia, hubungan dengan pasangan memburuk, frekuensi koitus semakin menurun, mengalami penyakit psikosomatis ( seperti mengeluh pusing yang terus menerus, mengalami diare yang sering, sesak nafas padahal tidak punya riwayat asma, dan mengalami gatal-gatal yang tidak ada penyebabnya.

Berdasarkan hasil penelitian, dari total 8 responden rawat jalan di Poli klinik Jantung RSUD Dr. Iskak Tulungagung, mengenai dampak gangguan pemenuhan kebutuhan seksualitas pasca serangan jantung Infark Miokard Akut didapatkan $100 \%$ responden tidak mengalami dampak gangguan pemenuhan kebutuhan seksualitasnya, akan tetapi jika dilihat dari setiap item pertanyaan ada beberapa yang mengalami dampak gangguan pemenuhan kebutuhan seksualitas. Tetapi dari semua prosentase di atas tidak sampai membuat responden mengalami dampak luas yang ditimbulkan akibat dari gangguan dalam pemenuhan kebutuhan seksualitas yang dialami suami setelah serangan Infark Miokard Akut. Responden dan pasangan memiliki koping bahwa disaat sudah memasuki usia tua, dimensi seksualitas mereka tidak hanya diekspresikan dengan hubungan koitus saja, tetapi yang lakukan mereka hanya saling mengerti dan menerima keadaan masing-masing yang selalu merawat antara satu dengan yang lain.

Dilihat dari usia responden yang sebagian besar berusia diatas 60 tahun yaitu sebanyak 5 orang, mereka mengatakan tidak masalah soal penurunan frekuensi coitus, karena menurut mereka disaat-saat usia sudah tua dimensi pemenuhan kebutuhan seksual tidak hanya diwujudkan dengan melakukan coitus saja, yang mereka butuhkan sekarang saling mengerti dan saling merawat antara satu dengan yang lain. Tetapi ada 3 pasangan (Istri) yang kadang-kadang bahkan sering merasa sedih dan mudah tersinggung jika tidak terpenuhi kebutuhan seksualnya. Ada juga 1 pasangan (Istri) yang terkadang tidak mau diajak melakukan hubungan seks kembali karena pasangan akan takut kecewa jika di tengah saat melakukan hubungan belum klimaks suami merasa lelah, sesak atau 
bahkan terjadi kembali serangan jantung yang sebelumnya. Dampak lain yang juga ditimbulkan ketika pasangan merasa tidak terpenuhi pemenuhan kebutuhan seksualitasnya pada usia ini antara lain terkadang 1 pasangan (Istri) merasa ditelantarkan oleh suami, padahal suami tidak bermaksud menelantarkannya, hanya saja suami takut jika mereka memulai kembali dan sering melakukan hubungan seks, penyakit yang masih dalam proses penyembuhan ini akan kembali menyerangnya karena mengingat usia diatas 60 tahun dan proses penyembuhan yang akan berlangsung lama. Menurut Harkness (2000) dalam penelitian Diana Irawati, 2011 yang berjudul Studi Fenomenologi Pengalaman Disfungsi Seksual Pasien Penyakit Ginjal Kronik Tahap Akhir di Rumah Sakit Islam Jakarta mengatakan bahwa adanya penurunan energi dan kelelahan yang dialami pasien dan akan membatasi dan menurunkan kemampuan pasien dalam berhubungan seksual, hal ini akan menimbulkan rasa bersalah terhadap pasangan dimana pada kondisi tersebut pasien memerlukan dukungan dari pasangan sementara pasien memiliki keterbatasan untuk dapat memenuhi kebutuhan seksual pasangan. Harkness juga mengutip hasil penelitian yang dilakukan Toorians et.al (1997) kelelahan dan perubahan fisik sangat mempengaruhi disfungsi seksual. Dan jika perasaan itu terus dialami oleh istri, istri akan merasa sering mengeluh sakit kepala dan terkadang mengalami diare yang tidak ada penyebab pastinya.

Untuk yang berusia dibawah 60 tahun hanya aja yaitu sebanyak 3 responden. Pasangan akan lebih banyak mengalami dampak tidak terpenuhinya kebutuhan seks, mungkin karena mereka masih aktifaktifnya dalam melakukan hubungan seks, karena sang istri belum mengalami menopouse. Sehingga ada 1 pasangan (istri) yang menolak ajakan untuk melakukan hubungan seks, yang sebelumnya istri akan ketus saat diajak berbicara tentang hubungan seksual.
Menurut Basaglia, dan Calanca dalam penelitian Juha T. Korpelainen, 1991 yang berjudul Sexual Functioning Among Stroke Patients and Their Spouses, studi diungkapkan oleh orang-orang yang negatif mempengaruhi hubungan mereka dengan istri mereka, dengan kecemasan dan frustrasi yang sering dilaporkan. Pasien merasa kurangnya harga diri atau takut akan ditolak oleh pasangan mereka karena stroke, dengan penurunan minat seksual atau perasaan menjadi tidak menarik. Ada lagi 1 pasangan (istri) yang terkadang merasa jika diabaikan, mudah tersinggung, dan akan merasa sedih jika istri merasa tidak terpenuhi kebutuhan seksualnya. Menurut Black dan Hawk (2009) dalam penelitian Diana Irawati, 2011 yang berjudul Studi Fenomenologi Pengalaman Disfungsi Seksual Pasien Penyakit Ginjal Kronik Tahap Akhir di Rumah Sakit Islam Jakarta yang mengatakan bahwa gangguan psikologis ini terjadi karena terjadinya stress akibat kondisi penyakit kronik yang dialami. Beberapa perilaku yang umumnya menjadi stressor adalah perasaan tidak berdaya, perubahan body image dan perubahan seksual. Seluruhnya frekuensi melakukan hubungan seks juga mengalami penurunan, yang sebelum sakit biasanya bisa 1 minggu 3 kali, setelah mengalami serangan Infark Miokard Akut hanya 1 minggu 2 kali atau 1 kali, bahkan ada yang terkadang 2 minggu hanya 1 kali melakukan hubungan seksualitas. Dari hasil penelitian yang dilakukan oleh Diana Irawati, 2011 yang berjudul Studi Fenomenologi Pengalaman Disfungsi Seksual Pasien Penyakit Ginjal Kronik Tahap Akhir di Rumah Sakit Islam Jakarta yang mengatakan bahwa frekuensi hubungan seksual responden mengalami penurunan yang ditandai dengan tidak adanya aktivitas seksual dan aktivitas seksual yang jarang. Dari hasil penelitian Soykan (2001) di Turki dalam penelitian Diana Irawati (2011) mengatakan dari 43 responden yang mengalami penyakit kronis, $40 \%$ tidak melakukan aktivitas 
seksual. Dampak-dampak di atas bisa terjadi karena pasangan (Istri) tidak mengerti tentang keadaan suami, sehingga sering terjadi kesalahan dalam komunikasi. Sebenarnya hal-hal diatas bisa diatasi jika pasangan mengerti akan keadaan suami, dan saat kontrol mereka lebih sering berkonsultasi kepada tenaga medis yang merawat tentang cara, tehnik, dan frekuensi melakukan hubungan seks yang lebih aman setelah serangan jantung ini dialaminya, sehingga responden dan pasangan (Istri) tidak sampai mengalami dampak dari gangguan pemenuhan kebutuhan seksualitas pasca serangan jantung (Infark Miokard Akut).

Berdasarkan hasil penelitian dari jumlah responden sebanyak 8 responden, seluruh responden $(100 \%)$ menyatakan tidak mengalami dampak gangguan dalam pemenuhan kebutuhan seksual.

Kebutuhan seksualitas adalah kebutuhan dasar manusia berupa ekspresi dua orang individu secara pribadi yang saling menghargai, memperhatikan, dan menyayangi sehingga terjadi sebuah hubungan timbal balik antara kedua individu tersebut (Hidayat,2006). Atau kesehatan seksual didefinisikan sebagai pengintegrasian somatik, emosional, intelektual, dan sosial dari kehidupan seksual, dengan cara yang positif memperkaya dan meningkatkan kepribadian, komunikasi, dan cinta (Perry $\&$ Potter, 2005).

Pria tidak mengalami perubahan hormonal yang dramatis atau kehilangan fertilisasi seperti yang dialami oleh wanita menopouse. Namun demikian mereka mengalami perubahan dalam respon seksual atau klimakterik. Pada usia 90 tahun, seorang pria mungkin mampu untuk sprematogenesis. Namun demikian, perlambatan kemampuan erektil dan ejakulatori yang dialami pada usia 50 atau 60 tahunan dapat menyebabkan kekhawatiran yang signifikan tentang potensi dan maskulinitas. Kebutuhan seksualitas merupakan kebutuhan dasar manusia yang juga harus terpenuhi seperti halnya makan dan minum. Akan tetapi, kita tidak bisa memaksakan pemenuhan kebutuhan seksual tersebut bisa terpenuhi pada pasien-pasien jantung, terutama Infark Miokard Akut ( IMA ). Karena suatu penyakit respon terhadap pemenuhan kebutuhan seksual pun ikut berubah. Alat genetal dan jaringan lunak tubuh lainnya yang berespon terhadap rangsangan seksual membutuhkan pasokan darah yang adekuat, karena suatu penyakit alat genetal dan jaringan lunak tubuh mengalami penurunan respon. Hormon mempengaruhi suasana hati seksual dan fungsi fisiologis dalam ekspresi seksual. Persendian dan otot harus menekuk dan meregang ketika tubuh memberikan ekspresi terhadap perasaan seksual. Suatu perubahan dalam sistem ini, klien mungkin harus mempelajari perilaku seksual yang baru. Perubahan dalam fungsi dan struktur tubuh sebagai akibat dari suatu penyakit mungkin tidak secara langsung mempengaruhi seksualitas tetapi dapat mempengaruhi perasaan-perasaan dan persepsi klien dalam hal keinginan dan rangsangan. Beberapa dampak yang dapat ditimbulkan akibat tidak terpenuhinya kebutuhan seksualitas, diantaranya sebagi berikut pasangan akan cepat marah, tidak bahagia, hubungan dengan pasangan memburuk, frekuensi koitus semakin menurun, mengalami penyakit psikosomatis ( seperti mengeluh pusing yang terus menerus, mengalami diare yang sering, sesak nafas padahal tidak punya riwayat asma, dan mengalami gatal-gatal yang tidak ada penyebabnya.

Berdasarkan hasil penelitian, dari total 8 responden rawat jalan di Poli klinik Jantung RSUD Dr. Iskak Tulungagung, mengenai dampak gangguan pemenuhan kebutuhan seksualitas pasca serangan jantung Infark Miokard Akut didapatkan $100 \%$ responden tidak mengalami dampak gangguan pemenuhan kebutuhan seksualitasnya, akan tetapi jika dilihat dari 
setiap item pertanyaan ada beberapa yang mengalami dampak gangguan pemenuhan kebutuhan seksualitas. Tetapi dari semua prosentase di atas tidak sampai membuat responden mengalami dampak luas yang ditimbulkan akibat dari gangguan dalam pemenuhan kebutuhan seksualitas yang dialami suami setelah serangan Infark Miokard Akut. Responden dan pasangan memiliki koping bahwa disaat sudah memasuki usia tua, dimensi seksualitas mereka tidak hanya diekspresikan dengan hubungan koitus saja, tetapi yang lakukan mereka hanya saling mengerti dan menerima keadaan masing-masing yang selalu merawat antara satu dengan yang lain.

Dilihat dari usia responden yang sebagian besar berusia diatas 60 tahun yaitu sebanyak 5 orang, mereka mengatakan tidak masalah soal penurunan frekuensi coitus, karena menurut mereka disaat-saat usia sudah tua dimensi pemenuhan kebutuhan seksual tidak hanya diwujudkan dengan melakukan coitus saja, yang mereka butuhkan sekarang saling mengerti dan saling merawat antara satu dengan yang lain. Tetapi ada 3 pasangan (Istri) yang kadang-kadang bahkan sering merasa sedih dan mudah tersinggung jika tidak terpenuhi kebutuhan seksualnya. Ada juga 1 pasangan (Istri) yang terkadang tidak mau diajak melakukan hubungan seks kembali karena pasangan akan takut kecewa jika di tengah saat melakukan hubungan belum klimaks suami merasa lelah, sesak atau bahkan terjadi kembali serangan jantung yang sebelumnya. Dampak lain yang juga ditimbulkan ketika pasangan merasa tidak terpenuhi pemenuhan kebutuhan seksualitasnya pada usia ini antara lain terkadang 1 pasangan (Istri) merasa ditelantarkan oleh suami, padahal suami tidak bermaksud menelantarkannya, hanya saja suami takut jika mereka memulai kembali dan sering melakukan hubungan seks, penyakit yang masih dalam proses penyembuhan ini akan kembali menyerangnya karena mengingat usia diatas 60 tahun dan proses penyembuhan yang akan berlangsung lama. Menurut Harkness (2000) dalam penelitian Diana Irawati, 2011 yang berjudul Studi Fenomenologi Pengalaman Disfungsi Seksual Pasien Penyakit Ginjal Kronik Tahap Akhir di Rumah Sakit Islam Jakarta mengatakan bahwa adanya penurunan energi dan kelelahan yang dialami pasien dan akan membatasi dan menurunkan kemampuan pasien dalam berhubungan seksual, hal ini akan menimbulkan rasa bersalah terhadap pasangan dimana pada kondisi tersebut pasien memerlukan dukungan dari pasangan sementara pasien memiliki keterbatasan untuk dapat memenuhi kebutuhan seksual pasangan. Harkness juga mengutip hasil penelitian yang dilakukan Toorians et.al (1997) kelelahan dan perubahan fisik sangat mempengaruhi disfungsi seksual. Dan jika perasaan itu terus dialami oleh istri, istri akan merasa sering mengeluh sakit kepala dan terkadang mengalami diare yang tidak ada penyebab pastinya.

Untuk yang berusia dibawah 60 tahun hanya sebagian kecil saja yaitu sebanyak 3 responden. Pasangan akan lebih banyak mengalami dampak tidak terpenuhinya kebutuhan seks, mungkin karena mereka masih aktif-aktifnya dalam melakukan hubungan seks, karena sang istri belum mengalami menopouse. Sehingga ada 1 pasangan (istri) yang menolak ajakan untuk melakukan hubungan seks, yang sebelumnya istri akan ketus saat diajak berbicara tentang hubungan seksual. Menurut Basaglia, dan Calanca dalam penelitian Juha T. Korpelainen, 1991 yang berjudul Sexual Functioning Among Stroke Patients and Their Spouses, studi diungkapkan oleh orang-orang yang negatif mempengaruhi hubungan mereka dengan istri mereka, dengan kecemasan dan frustrasi yang sering dilaporkan. Pasien merasa kurangnya harga diri atau takut akan ditolak oleh pasangan mereka karena stroke, dengan penurunan minat seksual atau perasaan menjadi tidak menarik. Ada lagi 1 pasangan (istri) yang 
terkadang merasa jika diabaikan, mudah tersinggung, dan akan merasa sedih jika istri merasa tidak terpenuhi kebutuhan seksualnya. Menurut Black dan Hawk (2009) dalam penelitian Diana Irawati, 2011 yang berjudul Studi Fenomenologi Pengalaman Disfungsi Seksual Pasien Penyakit Ginjal Kronik Tahap Akhir di Rumah Sakit Islam Jakarta yang mengatakan bahwa gangguan psikologis ini terjadi karena terjadinya stress akibat kondisi penyakit kronik yang dialami. Beberapa perilaku yang umumnya menjadi stressor adalah perasaan tidak berdaya, perubahan body image dan perubahan seksual. Seluruhnya frekuensi melakukan hubungan seks juga mengalami penurunan, yang sebelum sakit biasanya bisa 1 minggu 3 kali, setelah mengalami serangan Infark Miokard Akut hanya 1 minggu 2 kali atau 1 kali, bahkan ada yang terkadang 2 minggu hanya 1 kali melakukan hubungan seksualitas. Dari hasil penelitian yang dilakukan oleh Diana Irawati, 2011 yang berjudul Studi Fenomenologi Pengalaman Disfungsi Seksual Pasien Penyakit Ginjal Kronik Tahap Akhir di Rumah Sakit Islam Jakarta yang mengatakan bahwa frekuensi hubungan seksual responden mengalami penurunan yang ditandai dengan tidak adanya aktivitas seksual dan aktivitas seksual yang jarang. Dari hasil penelitian Soykan (2001) di Turki dalam penelitian Diana Irawati (2011) mengatakan dari 43 responden yang mengalami penyakit kronis, 40\% tidak melakukan aktivitas seksual. Dampak-dampak di atas bisa terjadi karena pasangan (Istri) tidak mengerti tentang keadaan suami, sehingga sering terjadi kesalahan dalam komunikasi. Sebenarnya hal-hal diatas bisa diatasi jika pasangan mengerti akan keadaan suami, dan saat kontrol mereka lebih sering berkonsultasi kepada tenaga medis yang merawat tentang cara, tehnik, dan frekuensi melakukan hubungan seks yang lebih aman setelah serangan jantung ini dialaminya, sehingga responden dan pasangan (Istri) tidak sampai mengalami dampak dari gangguan pemenuhan kebutuhan seksualitas pasca serangan jantung (Infark Miokard Akut).

\section{KESIMPULAN}

Berdasarkan hasil penelitian dan pembahasan dari penelitian di Poli Klinik Jantung RSUD dr.Iskak Tulungagung peneliti mengambil kesimpulan bahwa seluruh responden menyatakan tidak mengalami dampak dari gangguan dalam pemenuhan kebutuhan seksualitas pasca serangan jantung ( infark miokard akut ).

\section{SARAN}

Dari kesimpulan di atas peneliti mengajukan saran sebagai berikut:

1. Bagi aplikatif

a. Untuk perawat Poli Klinik Jantung

Setelah mengetahui dampak dari gangguan pemenuhan kebutuhan seksualitas pasca serangan jantung diharapkan perawat bisa memberikan health education tentang cara pemenuhan kebutuhan seksualitas pasca serangan jantung saat pasien kontrol di Poli Klinik Jantung.

2. Bagi Keilmuan

a. Untuk Profesi Keperawatan

Sebaiknya profesi keperawatan banyak memberikan penyuluhan tentang cara pemenuhan kebutuhan seksualitas pasca serangan jantung, karena hal ini masih dianggap tabu oleh masyarakat, sehingga penyuluhan ini penting untuk meningkatkan wawasan dan pengetahuan masyarakat.

b. Untuk Pendidikan

1) Institusi pendidikan sebaiknya dapat menambah literatur dan menambah fasilitas misalnya jurnal penelitian, sehingga memudahkan mahasiswa dalam menyusun penelitian.

2) Sebaiknya hasil penelitian ini sebagai bahan masukan dan informasi tambahan bagi pendidikan keperawatan tentang kebutuhan dasar manusia terutama pemenuhan kebutuhan seksualitas pasca serangan jantung. 
c. Sebaiknya penelitian selanjutnya bisa lebih menambah responden sehingga penelitian bisa lebih valid.

d. Sebaiknya hasil penelitian ini menjadi dasar untuk penelitian selanjutnya terkait kebutuhan seksualitas pasca serangan jantung terutama pasien Infark Miokard Akut laki-laki.

\section{DAFTAR PUSTAKA}

Haryanto, S. (2009). Terapi Seks.Yogyakarta:Kanisius.

Hidayat, A. (2007). Metode Penelitian Keperawatan dan Teknis Analisa Data. Jakarta : Salemba Medika.

\section{(2006). Pengantar} Kebutuhan Dasar Manusia. Jakarta: Salemba Medika.

Irawati, D.(2011). Studi Fenomenologi : Pengalaman Disfungsi Seksual Pasien Penyakit Ginjal Kronik Tahap Akhir Yang Menjalani Hemodialisa Di RS Islam Jakarta. Jakarta: Lontar UI

Muttaqin, A. (2009). Askep Klien dengan Gangguan Sistem Kardiovaskuler. Jakarta: Salemba Medika.

Notoatmodjo. (2008). Metodelogi Penelitian Kesehatan . jakarta : Rineka Cipta.

Nursalam. (2008). Konsep dan Penerapan Metodologi Penelitian Ilmu Keperawatan.Jakarta:Salemba Medika.

Potter, dan Perry. (2005). Buku Ajar Fundamental Keperawatan. Jakarta: EGC.

Safitri, A. (2002). Lecture Notes Kardiologi.Jakarta:Erlangga.
Subekti, N. (2009). Buku Saku Patofisiologi. Jakarta: EGC

Suyono, J. (1996). Pemilihan Uji Laboratorium yang Efektif. Jakarta: EGC.

Suyoto.(2011).Angka Kejadian Serangan Jantung Saat Melakukan Hubungan Seksualitas: http://newworld16.blogspot.com/20 12/05: Diakses pada tanggal $27 \mathrm{Mei}$ 2013.

Tobing, N.(2006).Seks Tuntutan Bagi Pria. Jakarta: PT.Elex Media komputindo.

Udjianti, W.(2010).Keperawatan Kardiovaskuler. Jakarta: Salemba Medika.

Wiyanto.(2010).Penyakit Fisik Akibat Tidak Terpenuhinya Kebutuhan Seksualitas:

http://dc397.4shared.com/doc/tf638 _y3/preview.html. Diakses pada tanggal 25 Oktober 2012.

Yasmin, L. (1993). Proses Keperawatan Pada Pasien dengan Gangguan Kardiovaskuler. Jakarta: EGC. 